University of Nebraska - Lincoln

DigitalCommons@University of Nebraska - Lincoln

\title{
Genetic Variability for Mineral Element Concentration of Crested Wheatgrass Forage
}

Kenneth P. Vogel

University of Nebraska-Lincoln, kvogel1@unl.edu

H. F. Maryland

USDA-ARS

P. E. Reece

University of Nebraska, Scottsbluff, preece1@unl.edu

J. F. S. Lamb

Follow this and additional works at: https://digitalcommons.unl.edu/usdaarsfacpub

Vogel, Kenneth P.; Maryland, H. F.; Reece, P. E.; and Lamb, J. F. S., "Genetic Variability for Mineral Element Concentration of Crested Wheatgrass Forage" (1989). Publications from USDA-ARS / UNL Faculty. 1882. https://digitalcommons.unl.edu/usdaarsfacpub/1882

This Article is brought to you for free and open access by the U.S. Department of Agriculture: Agricultural Research Service, Lincoln, Nebraska at DigitalCommons@University of Nebraska - Lincoln. It has been accepted for inclusion in Publications from USDA-ARS / UNL Faculty by an authorized administrator of DigitalCommons@University of Nebraska - Lincoln. 


\title{
Genetic Variability for Mineral Element Concentration of Crested Wheatgrass Forage
}

\author{
K. P. Vogel,* H. F. Mayland, P. E. Reece and J. F. S. Lamb
}

\begin{abstract}
Grass tetany is a complex metabolic disorder that causes substantial livestock. production losses and deaths in temperate regions of the world. It is caused by low levels of $\mathrm{Mg}$ or an imbalance of $\mathrm{K}$, $\mathrm{Ca}$, and $\mathrm{Mg}$ in forage consumed by animals. Development of grasses with improved nineral balance would be an economical means of minimizing losses from this malady. This study was conducted to determine if genetic variability exists among crested wheatgrasses, Agropyron cristatum (L.) Gaertner and $A$. desertorum (Fisher ex Link) Schultes, for forage $\mathrm{Mg}, \mathrm{Ca}, \mathrm{K}, \mathrm{Fe}, \mathrm{Zn}, \mathrm{Mn}, \mathrm{Cu}, \mathrm{Na}$, and $\mathrm{P}$ concentrations. Forage of spaced plants of 10 diverse crested wheatgrass strains was harvested from replicated plots at Lincoln and Alliance, NE, which differ markedly in climate, and analyzed for these minerals. There were genetic differences among strains over locations for $\mathrm{Ca}, \mathrm{Mg}$, and $\mathrm{Fe}$ concentration in the forage. There were differences among strains within locations but not over locations for $\mathrm{K}$. Strain differences in $\mathrm{Zn}, \mathrm{Mn}, \mathrm{Cu}, \mathrm{Na}$, and $\mathrm{P}$ concentrations of the forage were not significant $(P>0.05)$ when averaged over locations. Calcium and $\mathrm{Mg}$ were positively correlated $(r=0.40)$. These results indicate that it should be possible to breed crested wheatgrass with increased $\mathrm{Mg}$ and $\mathrm{Ca}$ concentrations in its forage, thus reducing grass tetany potential.
\end{abstract}

$\mathrm{C}^{\mathrm{s}}$ RESTED WHEATGRASS is a genetic complex comprised of several species. The most important species in North America are $A$. cristatum and $A$. desertorum, which are diploids and tetraploids, respectively (Asay and Dewey, 1983; Barkworth and Dewey, 1985). In this paper, these two species will be referred to as crested wheatgrass, as they are in commerce.

Crested wheatgrass, which is utilized primarily by ruminants, does not contain significant amounts of any antiquality factor or toxic compounds except for occasionally high levels of nitrates (Mayland, 1986). Ruminant livestock grazing crested wheatgrass in the spring, however, can be severely affected by grass tetany (hypomagnesemic tetany), which can result in livestock deaths and production losses (Mayland, 1986). Thirty percent of all livestock losses attributed to grass tetany in the USA are thought to occur in animals grazing crested wheatgrass (Mayland, 1986).

Grass tetany is a nutritional ruminant disease caused by a deficiency of $\mathrm{Mg}$. It is a complex disease because of interactions of $\mathrm{Ca}, \mathrm{K}$, inorganic $\mathrm{P}$, vitamin $\mathrm{D}$, and parathyroid hormone in the ruminant (Littledike and Cox, 1979; Littledike and Goff, 1987). High $\mathrm{K}$ levels in the diet reduce $\mathrm{Mg}$ absorption (Littledike and Cox, 1979). Milk fever (parturient hypocalcemia), which is due primarily to low availability of $\mathrm{Ca}$ to the ruminant, particularly during the initial stages of lactation, is often associated with grass tetany in lactating animals (Littledike and Cox, 1979; Littledike and

K.P. Vogel, USDA-ARS and Dep. of Agronomy, Univ. of Nebraska, Lincoln, NE 68583; H.F. Mayland, USDA-ARS, Snake River Conservation Res. Ctr., Route 1, Kimberly, ID 83341; P.E. Reece, Panhandle Res. and Extension Ct., Univ. of Nebraska, 4502 Ave. I, Scottsbluff, NE 69361; and J.F.S. Lamb, 1219 Front, Crookston, MI Received 17 Oct. 1988. *Corresponding author.

Published in Crop Sci. 29:1146-1150 (1989).
Goff, 1987). Calcium, $\mathrm{Mg}$, and $\mathrm{K}$ levels and the ratio $\mathrm{K} /(\mathrm{Mg}+\mathrm{Ca})$, in which elements are expressed as equivalents $\mathrm{kg}^{-1}$, are used to estimate the grass tetany potential of grass herbage.

Genetic variability for the concentration of these mineral elements and the $\mathrm{K} /(\mathrm{Ca}+\mathrm{Mg})$ ratio in grass forage has been reported for tall fescue (Festuca arundinaceae Schreber) (Nguyen and Sleper, 1981), reed canarygrass (Phalaris arundinaceae L.) (Hovin et al., 1978), and perennial ryegrass (Lolium perenne L.) (Sleper, 1979). Hides and Thomas (1981) demonstrated that it was possible to alter the $\mathrm{Mg}$ content of Italian ryegrass (Lolium multiflorum Lam.) by breeding. Mayland and Asay (1989) demonstrated the existence of genetic variability among 12 clones of $A$. desertorum and among 16 of the 18 original clones of 'Hycrest' crested wheatgrass for $\mathrm{Mg}, \mathrm{Ca}, \mathrm{K}$, and $\mathrm{K} /$ $(\mathrm{Ca}+\mathrm{Mg})$ in a study at Logan, UT. Broad-sense heritability estimates were determined from the replicated clones.

The objectives of this study were to: (i) determine if genetic variability exists among crested wheatgrass strains for the concentration of $\mathrm{K}, \mathrm{Ca}, \mathrm{Mg}, \mathrm{Fe}, \mathrm{Zn}$, $\mathrm{Mn}, \mathrm{Cu}, \mathrm{Na}$, and $\mathrm{P}$ in their forage, (ii) obtain preliminary estimates of the magnitude of genotype $X$ environment interaction effects, and (iii) determine the correlation of mineral element concentrations with other important agronomic traits.

\section{MATERIALS AND METHODS}

The crested wheatgrass and the field cultural procedures used in this study were described previously (Lamb et al., 1984; Vogel et al., 1984.) In brief, 42 crested wheatgrass strains representative of the array of germplasm available to breeders were grown in space-planted nurseries at Lincoln and Alliance, NE during the period 1979 to 1981. The Lincoln and Alliance experiments were located on a Kennebec soil (fine-silty, mixed, mesic, Cumulic Hapludoll) and a Keith soil (fine-silty, mixed, mesic, Aridic Arguistoll), respectively. Alliance is located $540 \mathrm{~km}$ west of Lincoln at about the same latitude. Its growing season is $40 \mathrm{~d}$ shorter than at Lincoln ( 120 vs. $160 \mathrm{~d}$ ) and its annual precipitation is half that of Lincoln $(400$ vs. $740 \mathrm{~mm})$. The specific climatic conditions at both locations during the study were described by Lamb et al. (1984).

Plots were single rows of 10 spaced plants with plants and rows spaced $1 \mathrm{~m}$ apart. The experimental design at both locations was a randomized complete block with four replicates. Plants in both nurseries were harvested for forage yield and sampled for forage quality in 1980 and 1981 after anthesis. Ten of the strains were harvested on an individual plant basis to obtain estimates of within-strain variation while the remaining strains were harvested on a plot basis. The strains harvested on an individual plant basis were used in this study. They included the released cultivars Nordan (tetraploid) and Ruff (diploid), six plant introduction (PI) lines (two tetraploids and four diploids), and two experimental lines (tetraploids). PI 370645 and PI 401003 are tetraploids and PIs 314596, 325180, 369167 and 369170 are diploids. One of the experimental lines, NE 10b-1, is a clonal line that was vegetatively propagated from a single plant of 
'Nebraska 10'. The strains selected for individual plant harvest were the superior strains in the nurseries based on visual evaluations in 1980 before the first harvest. At Lincoln, individual plants were harvested with hand sickles, while at Alliance they were cut with a plot mower. Harvest height was $13 \mathrm{~cm}$ at both locations. Forage subsamples $(200 \mathrm{~g}$ fresh weight) for quality and mineral element analyses were dried in forced air ovens at $65^{\circ} \mathrm{C}$, ground in a Wiley mill through a $1-\mathrm{mm}$ screen, and stored in sealed plastic vials. Samples from both years and locations were used to determine dry matter content, in vitro dry matter digestibility (IVDMD), and protein concentration. Results of those analyses are reported by Lamb et al. (1984). Only the 8001981 samples, 400 from each location, were used for the mineral analyses.

Forage subsamples were transferred to $75-$ by $135-\mathrm{mm}$ paper envelopes and dried at $40^{\circ} \mathrm{C}$ for about $24 \mathrm{~h}$ prior to analysis. Nitric-perchloric acid (3:1) digestion of $0.5 \mathrm{~g}$ forage subsamples preceded analysis for $\mathrm{Ca}, \mathrm{Cu}, \mathrm{Fe}, \mathrm{K}, \mathrm{Mg}, \mathrm{Mn}$, $\mathrm{Na}, \mathrm{P}$, and $\mathrm{Zn}$. Phosphorus was measured colorimetrically using the vanadomolybdate procedure. Potassium was determined by flame emission. All other elements were measured by atomic adsorption spectrophotometry. Samples for $\mathrm{K}, \mathrm{Ca}$, and $\mathrm{Mg}$ were prepared in $0.1 \%$ lanthanum (La) prior to analysis. A standard plant sample was included as a check on analytical procedures. Recovery of the National Bureau of Standards citrus leaves (NBS-1572) was 99, 98 and 98\% for $\mathrm{Ca}, \mathrm{Mg}$ and $\mathrm{K}$, respectively. Recovery of the other analyzed elements averaged 101\%. All 800 samples were analyzed for $\mathrm{Ca}, \mathrm{Mg}, \mathrm{K}$, and $\mathrm{Fe}$. Two hundred samples (two or three plants per plot) were analyzed for the complete mineral profile. The cation ratios $\mathrm{K} / \mathrm{Mg}$ and $\mathrm{K} /(\mathrm{Mg}+\mathrm{Ca})$ were calculated on an equivalents $\mathrm{kg}^{-1}$ basis.

The mean value for the plants in a plot was determined for all traits and the data set of these mean values was used in analyses of variance (ANOVA) for each location and in the across-locations ANOVA to test for strain differences and the significance of the strain $\times$ locations effect. Strains, replications, and locations were considered to be random effects in all standard analyses. Variances due to strains $\left(\sigma_{\mathrm{g}}^{2}\right)$, the interaction of locations and strains $\left(\sigma_{\mathrm{gl}}^{2}\right)$, and error $\left(\sigma_{\mathrm{e}}^{2}\right)$ and their standard errors were calculated from the mean squares of these ANOVAs using standard methods (Becker, 1984). The phenotypic variance $\left(\sigma_{\mathrm{p}}^{2}\right)$ was calculated as $\sigma_{\mathrm{p}}^{2}=$ $\sigma_{\mathrm{g}}^{2}+\sigma_{\mathrm{gl}}^{2}+\sigma_{\mathrm{e}}^{2}$.

Estimates of the variation within strains $\left(\sigma_{\mathrm{w}}^{2}\right)$ were also determined for $\mathrm{K}, \mathrm{Ca}, \mathrm{Mg}$, and the two ratios described previously. An ANOVA was conducted for all strains within a location using all the individual plant data. One strain was then deleted and the ANOVA was repeated on the modified data set. The within-strain sum of squares for the deleted strain was determined by subtracting the within-strain sum of squares of the deleted data set from the within-strain sum of squares of the complete individual plant data set. The within strain variance for the deleted data set was determined by simply dividing the within-strain sum of squares by the within-strain degrees of freedom for that strain. This process was repeated for all 10 entries for both locations for a total of 22 ANOVAs for each trait.

Pearson correlation coefficients were determined among all traits using individual plant data from both locations (Steel and Torrie, 1960).

\section{RESULTS AND DISCUSSION}

\section{Genetic Variation Among Strains}

There were genetic differences among the crested wheatgrass strains for forage $\mathrm{K}$ concentrations (Table
1). However these differences were small when averaged across locations probably because of a significant genotype $\times$ location $(G \times L)$ interaction effect, i.e., the strains did not rank similarly in $K$ concentration at the two locations.

There were genetic differences among the strains for $\mathrm{Ca}$ content at Lincoln and averaged across locations, although the differences were small at Alliance. Genetic differences existed among the crested wheatgrass strains for $\mathrm{Mg}, \mathrm{Fe}$, and the ratio $\mathrm{K} / \mathrm{Mg}$ at both locations and averaged across locations. There were significant $(P<0.05)$ genetic differences among the strains for $\mathrm{P}$ and the ratio $\mathrm{K} /(\mathrm{Ca}+\mathrm{Mg})$ only at Lincoln. The strains did not differ for $\mathrm{Zn}, \mathrm{Mn}, \mathrm{Cu}$, and $\mathrm{Na}$ concentration of the forage averaged over locations. Genotype $\times$ location effects were not significant $(P>0.05)$ except for $\mathrm{K}$ and $\mathrm{Fe}$ and the ratio $\mathrm{K} /(\mathrm{Ca}$ $+\mathrm{Mg}$ ) indicating that, except for these elements and ratio, the relative genetic differences among crested wheatgrass strains for mineral content were similiar at the two locations.

The $\mathrm{G} \times \mathrm{L}$ interaction effect for the ratio $\mathrm{K} /(\mathrm{Ca}+$ $\mathrm{Mg}$ ) was probably significant because of the effect of $K$. It is recognized that the genotype $X$ environment interaction results are based on the minimum number of environments. These environments, however, differed markedly (Lamb et al., 1984).

The mean and range values for the forage mineral element concentrations for Lincoln and Alliance are summarized in Table 2. Recommended mineral concentrations of forages for ruminants vary with age, sex, and physiological condition of the animals (NAS/ NRC, 1976; Reid and James, 1985; Working Party on Nutrient Requirements of Ruminants, 1980). Recommendations on minimium mineral element concentrations needed for ruminants also vary somewhat with authority, but all authorities agree that lactating animals have the highest mineral requirements. In terms of mineral requirements of a lactating beef cow (Bos taurus), the mineral element concentrations of the crested wheatgrass forage harvested at Lincoln and Alliance can be classified as follows: $\mathrm{K}$, adequate; $\mathrm{Ca}$, adequate to low; $\mathrm{Mg}$, inadequate; $\mathrm{P}$, inadequate; $\mathrm{Fe}$,

Table 1. Summary of analyses of variance for mineral element concentrations of crested wheatgrass grown at Lincoln and Alliance, NE.

\begin{tabular}{|c|c|c|c|c|}
\hline \multirow[b]{3}{*}{$\begin{array}{l}\text { Mineral } \\
\text { element }\end{array}$} & \multicolumn{4}{|c|}{ Statistical significance of mean squares } \\
\hline & \multicolumn{3}{|c|}{ Strains } & \multirow{2}{*}{$\frac{\mathrm{G} \times \mathbf{L} \dagger}{\begin{array}{c}\text { Across } \\
\text { locations }\end{array}}$} \\
\hline & Lincoln & Alliance & $\begin{array}{c}\text { Across } \\
\text { locations }\end{array}$ & \\
\hline $\mathbf{K}$ & ** & ** & NS $\ddagger ; P=0.07$ & $*$ \\
\hline $\mathrm{Ca}$ & ** & $\mathrm{NS} ; P=0.11$ & * & NS \\
\hline $\mathbf{M g}$ & ** & ** & $* *$ & NS \\
\hline $\mathbf{P}$ & * & NS & NS & NS \\
\hline $\mathbf{K} /(\mathrm{Ca}+\mathrm{Mg})$ & ** & $\mathrm{NS} ; P=0.07$ & NS & * \\
\hline $\mathrm{K} / \mathrm{Mg}$ & ** & $* *$ & $* *$ & NS; $P=0.08$ \\
\hline $\mathrm{Fe}$ & $*$ & $* *$ & $*$ & $*$ \\
\hline $\mathrm{Zn}_{\mathbf{n}}$ & NS & NS & NS & NS \\
\hline Mn & NS & NS & NS & NS \\
\hline $\mathrm{Cu}$ & NS & NS & NS; $P=0.06$ & NS \\
\hline $\mathrm{Na}$ & NS & $*$ & NS & NS \\
\hline
\end{tabular}

*** Indicates significance at the 0.05 and the 0.01 levels of probability, respectively, based on an $F$ test.

$+\mathrm{G} \times \mathrm{L}=$ Strain $\times$ location interaction effect.

$\ddagger \mathrm{NS}=$ Not significant at $P=0.05$ based on an $F$ test. 
adequate; $\mathrm{Zn}$, adequate; $\mathrm{Mn}$, adequate; $\mathrm{Cu}$, adequate to low; $\mathrm{Na}$ inadequate.

The $\mathrm{K} /(\mathrm{Ca}+\mathrm{Mg})$ ratio should be 2.2 or less for the forage to be "safe" in terms of its potential for inducing grass tetany in lactating cows (Sleper, 1979). The $\mathrm{K} /(\mathrm{Mg}+\mathrm{Ca})$ ratio at both locations was less than this critical level (Table 2$)$. The ratio $\mathrm{K} /(\mathrm{Ca}+\mathrm{Mg})$ estimates the forage's potential to induce either hypomagnesemic tetany or parturient hypocalcemia or both in ruminants, while $\mathrm{K} / \mathrm{Mg}$ is more applicable to hypomagnesemic tetany. Appropriate values for the $\mathrm{K} /$ $\mathrm{Mg}$ ratio have not been established. The mineral element concentration of forages change during the growing season and their availability to animals also changes with maturity. Available $\mathrm{Mg}$ is generally larger and the $\mathrm{K} /(\mathrm{Mg}+\mathrm{Ca}$ ) ratios are usually lower for grasses harvested at heading than for grasses harvested earlier in the growing season (Mayland and Grunes, 1979). The minimum recommended level for $\mathrm{Mg}$ is 1.5 to $2.0 \mathrm{~g} \mathrm{~kg}^{-1}$. Hence, the mean and range values in Table 2 indicate that the $\mathrm{Mg}, \mathrm{P}$, and $\mathrm{Na}$ levels of crested wheatgrass forage need to be improved to meet the requirements of lactating beef cows.

The among-strain genetic variances $\left(\sigma_{g}^{2}\right)$ for $\mathrm{Na}$ and $P$ were zero (Table 3 ). The genetic variances for all the other elements were greater than zero but they were low for $\mathrm{Zn}, \mathrm{Mn}$, and $\mathrm{Cu}$. The ratio $\sigma_{\mathrm{g}}^{2} / \sigma_{\mathrm{p}}^{2}$ (genotypic to phenotypic variance) provides an estimate of the proportion of the among-strain variation attributable to genetic effects. This ratio is similiar to a heritability estimate but the term heritability is inappropriate because the strains are not the progeny of a reference population. The $\sigma_{\mathrm{g}}^{2} / \sigma_{\mathrm{p}}^{2}$ ratio was greater than 0.30 for $\mathrm{K}, \mathrm{Ca}, \mathrm{Mg}, \mathrm{Fe}$, and $\mathrm{K} / \mathrm{Mg}$ (Table 3). The ratio was 0.50 for $\mathrm{Mg}$ indicating that a substantial proportion of the total variation among strains for $\mathrm{Mg}$ was due to genetic effects. The $\sigma_{\mathrm{gl}}^{2}$ effect for $\mathrm{K}$ was almost as large as the $\sigma_{\mathrm{g}}^{2}$ effect, which again indicates that the concentration of this element in crested wheatgrass strains relative to other strains varies considerably with environments. Thus, of the three elements that are deficient in crested wheatgrass forage, only $\mathrm{Mg}$ appears to be amenable to improvement by selection among strains. The $\mathrm{Ca}$ content of crested wheatgrass forage, which is low, could also be improved by selection among strains.

\section{Within Strain Variation}

The variance among plants within strains $\left(\sigma_{\mathrm{w}}^{2}\right)$ was determined for each strain at each location for $\mathrm{K}, \mathrm{Ca}$, $\mathrm{Mg}, \mathrm{K} /(\mathrm{Ca}+\mathrm{Mg})$, and $\mathrm{K} / \mathrm{Mg}$ (Table 4). The withinstrain variance, $\sigma_{w}^{2}$, for the clonal line, NE $10 \mathrm{~b}-1$, consisted entirely of plant-to-plant environmental variation and experimental error, while for the other strains it consisted of the same factors plus the within-strain genetic variance among plants. Comparison of $\sigma_{\mathrm{w}}^{2}$ of NE $10 \mathrm{~b}-1$ with $\sigma_{w}^{2}$ of the other lines thus provides an estimate of the proportion of the variation among plants of a strain that are due to genetic differences among plants. Although it seems reasonable to assume that the among-plant environmental variance and experimental error of the plants propagated by seed would be the same as for the clonal line, it cannot be
Table 2. Mean and range values for mineral element concentrations and mineral element ratios in forage of crested wheatgrass strains grown at Lincoln and Alliance, NE.

\begin{tabular}{|c|c|c|c|c|}
\hline \multirow{2}{*}{$\begin{array}{l}\text { Mineral } \\
\text { element }\end{array}$} & \multicolumn{2}{|c|}{ Lincoln } & \multicolumn{2}{|c|}{ Alliance } \\
\hline & $\overline{\mathrm{X}} \pm \mathrm{SE}$ & Range & $\bar{X} \pm S E$ & Range \\
\hline & & 8 & -1 & \\
\hline $\begin{array}{l}\mathrm{K} \\
\mathrm{Ca} \\
\mathrm{Mg} \\
\mathrm{P}\end{array}$ & $\begin{array}{r}15.3 \pm 0.5 \\
2.7 \pm 0.1 \\
1.0 \pm 0.1 \\
1.6 \pm 0.1\end{array}$ & $\begin{array}{c}12.7-17.6 \\
2.2-3.3 \\
0.9-1.2 \\
1.5-1.8\end{array}$ & $\begin{array}{r}11.1 \pm 0.5 \\
2.8 \pm 0.2 \\
1.0 \pm 0.1 \\
1.5 \pm 0.1\end{array}$ & $\begin{array}{c}10.0-12.8 \\
2.4-3.2 \\
0.8-1.2 \\
1.4-1.6\end{array}$ \\
\hline $\begin{array}{l}\mathrm{K} /(\mathrm{Ca}+\mathrm{Mg}) \\
\mathbf{K} / \mathbf{M g}\end{array}$ & $\begin{array}{l}1.8 \pm 0.1 \\
4.8 \pm 0.2\end{array}$ & $\begin{array}{l}1.5-2.3 \\
3.7-6.4\end{array}$ & $\begin{array}{l}1.4 \pm 0.1 \\
3.8 \pm 0.3\end{array}$ & $\begin{array}{l}1.0-1.6 \\
2.6-4.7\end{array}$ \\
\hline $\begin{array}{l}\mathrm{Fe} \\
\mathrm{Zn} \\
\mathrm{Mn} \\
\mathrm{Cu} \\
\mathrm{Na}\end{array}$ & $\begin{array}{r}247 \pm 22 \\
18 \pm 2 \\
32 \pm 4 \\
3 \pm 0.3 \\
42 \pm 6\end{array}$ & $\begin{array}{c}188-297 \\
15-20 \\
25-42 \\
2.8-3.6 \\
37-56\end{array}$ & $\begin{aligned} 331 & \pm 28 \\
19 & \pm 3 \\
44 & \pm 7 \\
4 & \pm 0.3 \\
36 & \pm 2\end{aligned}$ & $\begin{array}{c}235-449 \\
16-24 \\
34-58 \\
3.0-4.1 \\
30-40\end{array}$ \\
\hline
\end{tabular}

Table 3. Variance component estimates for mineral element concentrations and mineral element ratios in crested wheatgrass forage from the across locations ANOVA.

\begin{tabular}{|c|c|c|c|c|}
\hline \multirow{2}{*}{$\begin{array}{l}\text { Mineral } \\
\text { element }\end{array}$} & \multicolumn{4}{|c|}{ Variance components $\dagger \pm$ SE $\ddagger$} \\
\hline & $\sigma_{\mathrm{B}}^{2}$ & $\sigma_{\mathrm{g}}^{2}$ & $\sigma_{e}^{2}$ & $\sigma_{\mathrm{g}}^{2} / \sigma_{\mathrm{p}}^{2}$ \\
\hline $\mathbf{K}$ & $1.03 \pm 0.73$ & $0.94 \pm 0.48$ & $0.88 \pm 0.17$ & 0.36 \\
\hline $\mathrm{Ca}$ & $0.04 \pm 0.03$ & $0.01 \pm 0.01$ & $0.09 \pm 0.12$ & 0.42 \\
\hline $\mathbf{M g}$ & $0.01 \pm 0.01$ & $0.00 \pm 0.01$ & $0.01 \pm 0.01$ & 0.50 \\
\hline & $0.0 \pm 0.0$ & $0.0 \pm 0.0$ & $0.02 \pm 0.00$ & 0.00 \\
\hline $\mathrm{K} /(\mathrm{Ca}+\mathbf{M g})$ & $0.01 \pm 0.01$ & $0.01 \pm 0.00$ & $0.04 \pm 0.01$ & 0.17 \\
\hline $\mathrm{K} / \mathrm{Mg}$ & $0.39 \pm 0.19$ & $0.05 \pm 0.04$ & $0.23 \pm 0.04$ & 0.58 \\
\hline $\mathrm{Fe}$ & $2191 \pm 1310$ & $903 \pm 677$ & $2636 \pm 498$ & 0.38 \\
\hline $\mathbf{Z n}$ & $1.8 \pm 1.5$ & $0.0 \pm 1.6$ & $22.3 \pm 4.2$ & 0.08 \\
\hline Mn & $1 \pm 11$ & $2 \pm 16$ & $134 \pm 25$ & 0.01 \\
\hline $\mathrm{Cu}$ & $0.05 \pm 0.03$ & $0.0 \pm 0.02$ & $0.32 \pm 0.06$ & 0.14 \\
\hline $\mathrm{Na}$ & $0.0 \pm 6$ & $4 \pm 11$ & $82 \pm 15$ & 0.00 \\
\hline
\end{tabular}

$\dagger \sigma_{\mathrm{g}}^{2}=$ variance due to strains; $\sigma_{\mathrm{g} 1}^{2}=$ variance due to the interaction of location and strains; $\sigma_{\mathrm{e}}^{2}=$ plot error variance; $\sigma_{\mathrm{p}}^{2}=\sigma_{\mathrm{g}}^{2}+\sigma_{\mathrm{g}}^{2}+\sigma_{\mathrm{g}}^{2}=$ phenotypic variance.

$\ddagger \mathrm{SE}$ of 0.00 indicates SE was $<0.005$.

tested with the available data. Hence we can only draw general inferences from the within-strain variances.

At Lincoln, $\sigma_{\mathrm{w}}^{2}$ was at least twice as large for all elements and ratios evaluated for the lines propagated by seed as for NE $10 b-1$ except for the ratio $\mathrm{K} / \mathrm{Mg}$ for some lines (Table 4). At Alliance, only the variance for Ca was larger for all lines propagated by seed than for the clonal line. Some of the lines propagated by seed at Alliance had larger $\sigma_{\mathrm{w}}^{2}$ values than the clonal line for $\mathrm{Mg}$ and $\mathrm{K} /(\mathrm{Ca}+\mathrm{Mg})$. The $\sigma_{\mathrm{w}}^{2}$ values at $\mathrm{Al}-$ liance were higher for the clonal line than for the other strains for $\mathrm{K}$ and the ratio $\mathrm{K} / \mathrm{Mg}$. These results indicate that there was substantial within-strain genetic variability among strains for the traits evaluated when the strains were grown at Lincoln. However, at Alliance, the within-strain genetic variability among strains was considerably smaller, except for $\mathrm{Ca}$. There was genetic variation within some of the strains for $\mathrm{Mg}$ at Alliance. The within-strain genetic variation of crested wheatgrass is probably due to additive effects because of its mating system and the methods used to propagate the strains, and hence could be used to improve the grass in a breeding program.

\section{Breeding Potential}

The between-strain genetic variances (Table 3 ) and the apparent magnitude of the within-strain genetic 
Table 4. Within-strain variation ( $\left.\sigma_{\mathrm{w}}^{2}\right)$ for 'Ruff', 'Nordan', NE 10b-1 (a clonal line), and seven PI or experimental crested wheatgrass strains.

\begin{tabular}{|c|c|c|c|c|c|c|c|c|c|c|}
\hline \multirow[b]{2}{*}{ Location/strain } & \multicolumn{2}{|c|}{$\mathrm{K}$} & \multicolumn{2}{|c|}{$\mathrm{Ca}$} & \multicolumn{2}{|c|}{$\mathrm{Mg}$} & \multicolumn{2}{|c|}{$\mathrm{K} /(\mathrm{Ca}+\mathrm{Mg})$} & \multicolumn{2}{|c|}{$\mathrm{K} / \mathrm{Mg}$} \\
\hline & $\overrightarrow{\mathrm{X}}$ & $\sigma_{w}^{2}$ & $\overline{\mathbf{X}}$ & $\sigma_{w}^{2}$ & $\overline{\mathrm{X}}$ & $\sigma_{w}^{2}$ & $\overline{\mathrm{x}}$ & $\sigma_{\mathrm{w}}^{2}$ & $\bar{X}$ & $\sigma_{w}^{2}$ \\
\hline & & & 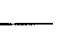 & $\mathrm{kg}^{-1} \longrightarrow$ & 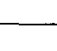 & 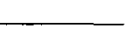 & 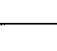 & 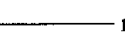 & + & 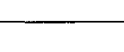 \\
\hline \multicolumn{11}{|l|}{$\underline{\text { Lincoln }}$} \\
\hline $\begin{array}{l}\text { Ruff } \\
\text { Nordan } \\
\text { Range of PI or exp. strains } \dagger \\
\text { NE 10b-1 }\end{array}$ & $\begin{array}{l}17.1 \\
14.5 \\
17.6\end{array}$ & $\begin{array}{c}5.53 \\
4.38 \\
2.40-9.01 \\
1.64\end{array}$ & $\begin{array}{l}2.2 \\
2.9\end{array}$ & $\begin{array}{c}0.16 \\
0.36 \\
0.20-0.79 \\
0.10\end{array}$ & $\begin{array}{l}1.1 \\
1.0 \\
0.9\end{array}$ & $\begin{array}{c}0.02 \\
0.02 \\
0.01-0.04 \\
0.00 \dagger\end{array}$ & $\begin{array}{l}2.3 \\
1.7 \\
1.9\end{array}$ & $\begin{array}{c}0.43 \\
0.15 \\
0.12-1.00 \\
0.04\end{array}$ & $\begin{array}{l}5.1 \\
4.9 \\
6.4\end{array}$ & $\begin{array}{c}2.64 \\
1.22 \\
0.50-1.62 \\
0.48\end{array}$ \\
\hline \multicolumn{11}{|l|}{ Alliance } \\
\hline $\begin{array}{l}\text { Ruff } \\
\text { Nordan } \\
\text { Range of PI or exp. strainsł } \\
\text { NE 10b-1 }\end{array}$ & $\begin{array}{l}11.0 \\
11.2\end{array}$ & $\begin{array}{c}2.21 \\
2.61 \\
0.91-5.36 \\
5.88\end{array}$ & $\begin{array}{l}2.7 \\
3.0\end{array}$ & $\begin{array}{c}0.26 \\
0.32 \\
0.15-0.39 \\
0.08\end{array}$ & $\begin{array}{l}1.0 \\
0.9\end{array}$ & $\begin{array}{c}0.03 \\
0.01 \\
0.01-0.04 \\
0.02\end{array}$ & $\begin{array}{l}1.4 \\
1.3\end{array}$ & $\begin{array}{c}0.09 \\
0.09 \\
0.02-0.11 \\
0.06\end{array}$ & $\begin{array}{l}3.7 \\
3.9\end{array}$ & $\begin{array}{c}0.68 \\
0.67 \\
0.15-0.81 \\
0.98\end{array}$ \\
\hline
\end{tabular}

$\dagger$ Range of means are listed in Table 2.

$\ddagger \sigma_{\mathrm{w}}^{2}$ was $<0.005$.

Table 5. Correlations of mineral element concentrations, mineral element ratios, and other traits of crested wheatgrass forage when harvested after head emergence. $\dagger$

\begin{tabular}{|c|c|c|c|c|c|c|c|c|c|c|c|}
\hline Traits & $\mathrm{Ca}$ & $\mathbf{K}$ & $\mathbf{M g}$ & $\mathbf{F e}$ & $\mathrm{Zn}$ & Mn & $\mathrm{Cu}$ & $\mathrm{Na}$ & $\mathbf{P}$ & $\mathrm{K} / \mathrm{Mg}$ & $\mathrm{K} /(\mathrm{Ca}+\mathrm{Mg})$ \\
\hline $\mathrm{K}$ & 0.02 & & & & & & & & & & \\
\hline $\mathrm{Mg}$ & $0.40^{* *}$ & $0.10^{* *}$ & & & & & & & & & \\
\hline $\mathrm{Fe}$ & $0.16^{* *}$ & $-0.21^{* *}$ & $0.26^{* *}$ & & & & & & & & \\
\hline $\mathrm{Zn}$ & $0.25^{* *}$ & -0.02 & 0.05 & $0.17 *$ & & & & & & & \\
\hline $\mathrm{Mn}$ & $0.39^{* *}$ & $-0.33^{* *}$ & $0.19^{* *}$ & $0.36^{* *}$ & $0.56^{* *}$ & & & & & & \\
\hline $\mathrm{Cu}$ & $0.21^{* *}$ & 0.00 & $0.15^{*}$ & 0.13 & $0.18^{* *}$ & $0.26^{* *}$ & & & & & \\
\hline $\mathrm{Na}$ & $0.10^{* *}$ & 0.08 & 0.11 & 0.02 & -0.05 & -0.07 & 0.07 & & & & \\
\hline $\mathrm{P}$ & $0.15^{*}$ & $0.29^{* *}$ & 0.07 & -0.04 & $0.29^{* *}$ & 0.05 & 0.12 & -0.05 & & & \\
\hline $\mathrm{K} / \mathrm{Mg}$ & $-0.22^{* *}$ & $0.73^{* *}$ & $-0.56^{* *}$ & $-0.33^{* *}$ & -0.02 & $-0.35^{* *}$ & -0.08 & -0.01 & $0.17 *$ & & \\
\hline $\mathrm{K} /(\mathrm{Ca}+\mathrm{Mg})$ & $-0.54^{* *}$ & $0.76^{* *}$ & $-0.33^{* *}$ & $-0.30^{* *}$ & -0.08 & $-0.43^{* *}$ & -0.13 & 0.00 & $0.14^{*}$ & $0.84^{* *}$ & \\
\hline Height & $-0.16^{* * *}$ & $0.15^{* *}$ & $-0.35^{* *}$ & $-0.47^{* *}$ & -0.04 & $-0.18^{*}$ & $-0.14^{*}$ & 0.08 & 0.09 & $0.33^{* *}$ & $0.26^{* *}$ \\
\hline Yield & $-0.25^{\star * *}$ & $0.25^{* *}$ & $-0.26^{* *}$ & $-0.39^{* *}$ & $-0.24^{* *}$ & $0.33^{* *}$ & $-0.18^{*}$ & 0.05 & -0.06 & $0.35^{* *}$ & $0.35^{* *}$ \\
\hline IVDMD\%‡ & 0.01 & -0.06 & $0.14^{* *}$ & $0.15^{* *}$ & $-0.16^{*}$ & 0.02 & 0.12 & 0.00 & -0.10 & $0.13^{* *}$ & -0.06 \\
\hline Protein $\%$ & $0.18 * *$ & $0.64^{* *}$ & $0.32^{* *}$ & $-0.13^{* * *}$ & 0.10 & $-0.18^{* *}$ & 0.00 & 0.13 & 0.45 & $0.30^{* *}$ & $0.35^{* *}$ \\
\hline Dry matter \% & $-0.16^{* *}$ & $-0.25^{* *}$ & $-0.12^{* *}$ & $0.08^{*}$ & -0.09 & -0.04 & $-0.21^{* *}$ & 0.04 & $-0.20^{* *}$ & $-0.14^{* *}$ & $-0.09^{* *}$ \\
\hline Heading date§ & 0.05 & $-0.25^{* *}$ & $0.24^{* *}$ & $0.34^{* *}$ & 0.10 & $0.20^{* *}$ & $0.15^{*}$ & $-0.20^{* *}$ & -0.06 & -0.34 & $-0.25 * *$ \\
\hline
\end{tabular}

*,** Indicates significance at the 0.05 and .01 levels of probability, respectively.

$\dagger N=800$ for all traits except for $\mathrm{Zn}, \mathrm{Mn}, \mathrm{Cu}, \mathrm{Na}$, and $\mathrm{P}$ for which $N=200$.

$\S$ Day of the year.

† IVDMD $=$ in vitro dry matter digestibility.

variances (Table 4) indicate that it should be possible to breed for improved $\mathrm{Ca}$ and $\mathrm{Mg}$ concentration in crested wheatgrass by conducting an among- and within-strain breeding program. It may be possible to improve the $\mathrm{K} /(\mathrm{Ca}+\mathrm{Mg})$ ratio by breeding to improve the $\mathrm{Ca}$ and $\mathrm{Mg}$ concentration of the forage. It will be very difficult to change the $K$ concentration of the forage for potential cultivars that will be used over a wide geographical area because of the apparent large genotype $X$ environment interaction effects for $K$ content. Attempting to change the $\mathrm{K} /(\mathrm{Ca}+\mathrm{Mg})$ ratio by breeding only for the $\mathrm{K}$ component of the ratio would appear to be difficult. These results are consistent with those reported by Mayland and Asay (1989).

A similar range in values for most elements was found among both the $A$. desertorum and the $A$. cristatum strains. This suggested that ploidy level per se was not an indicator of relative mineral element concentration among crested wheatgrass strains. The $\mathrm{Ca}$ and $\mathrm{Mg}$ concentration of both types of crested wheatgrass could be improved by breeding.

Calcium was positively correlated with the other minerals tested except for $\mathrm{K}$ (Table 5). The highest correlations were with $\mathrm{Mg}$. Calcium was also positively correlated with protein, but its correlation with forage yield was negative. The correlation of $\mathrm{Mg}$ with the other elements was positive but often low or not significant, except for $\mathrm{Ca}$. Magnesium was positively correlated with IVDMD and protein but was negatively correlated with yield. The negative correlations of $\mathrm{Ca}$ and $\mathrm{Mg}$ with forage yield were low $(r \leq 0.26)$ but significant $(P<0.01)$. Both $\mathrm{Ca}$ and $\mathrm{Mg}$ were negatively correlated with the ratios $\mathrm{K} /(\mathrm{Ca}+\mathrm{Mg})$ and $\mathrm{K} / \mathrm{Mg}$, which is highly desirable since low ratios are associated with reduced levels of grass tetany.

\section{CONCLUSION}

The results of this study indicate that it should be possible to breed crested wheatgrass for improved $\mathrm{Mg}$ and $\mathrm{Ca}$ concentration. Selecting for improved $\mathrm{Ca}$ and $\mathrm{Mg}$ should result in a decreased $\mathrm{K} /(\mathrm{Ca}+\mathrm{Mg}$ ) ratio and slightly increased or stable IVDMD and protein content of the forage. Selection for $\mathrm{Ca}$ and $\mathrm{Mg}$ could result in reduced forage yields unless selection pressure also was applied to forage yields, since $\mathrm{Ca}$ and $\mathrm{Mg}$ are negatively correlated with forage yield. It does not appear feasible to breed for increased $\mathrm{Na}$ and $\mathrm{P}$ content of crested wheatgrass forage. Breeding for increased $\mathrm{Ca}$ and $\mathrm{Mg}$ concentration could result in strains with reduced grass tetany potential, which could result in significant reductions in animal losses for livestock producers.

The results of this study may be criticized since the plants were sampled at a single stage of development. 
This was done in order to limit the number of samples that needed to be analyzed, and also to obtain yield estimates. We sampled at anthesis because we reasoned that, by this stage of development, the plants would not be accumulating any significant additional dry matter and the mineral element concentration of the forage would represent an accumulative average of the mineral element concentration for the growing season. In a subsequent grazing study at Mead, NE which is about $45 \mathrm{~km}$ north of Lincoln, replicated pastures of Ruff and Nordan crested wheatgrass were sampled during a 6-wk period beginning in April and ending in June for $3 \mathrm{yr}$. The relative differences in mineral concentration for Ruff and Nordan averaged over the grazing season were similar to those based on sampling at anthesis in this study (K.P. Vogel, B.C. Gabrielsen, J.K. Ward, H.L. Mayland, and B. Anderson, 1988, personal communication). Results reported by Mayland and Asay (1989) and Sleper et al. (1980) also indicate that genetic differences among genotypes of crested wheatgrass and tall fescue, respectively, are relatively consistent over cuttings and environments. Additional studies will have to be conducted to determine the magnitude of the stage-of-growth $\times$ genotype interaction effect on mineral element concentration in crested wheatgrass. It is now possible to do this type of study using the strains that we have identified as differing in forage mineral concentration.

\section{REFERENCES}

Asay, K.H., and D.R. Dewey. 1983. Pooling the genetic resources of the crested wheatgrass complex. Proc. 14th Int. Grassl. Congr. 14:124-127.

Barkworth, M.E., and D.R. Dewey. 1985. Genomically based genera in the perennial triticeae of North America: Identification and membership. Am. J. Bot. 72:767-776.

Becker, W.A. 1984. Manual of quantitative genetics. 4th ed. Academic Enterprises, Pullman, WA.

Hides, D.H., and T.A. Thomas. 1981. Variation in the magnesium content of grasses and its improvement by selection. J. Sci. Food Agric. 32:990-991.

Hovin, A.W., T.L. Tew, and R.E. Stucker. 1978. Genetic variability for mineral elements in reed canarygrass. Crop Sci. 18:423-427.

Lamb, J.F.S., K.P. Vogel, and P.E. Reece. 1984. Genotype and genotype $X$ environment interaction effects on forage yield and quality of crested wheatgrasses. Crop Sci. 24:559-564.

Littledike, E.T., and P.S. Cox. 1979. Clinical, mineral, and endocrine interrelationships in hypomagnesemic tetany. p. 1-50. In V.V. Rendig and D.L. Grunes (ed.). Grass tetany. ASA Spec. Publ. 35. ASA, CSSA, and SSSA, Madison, WI.

Littledike, E.T., and J. Goff. 1987. Interactions of calcium, phosphorus, magnesium, and vitamin $\mathbf{D}$ that influence their status in domestic meat animals. J. Anim. Sci. 65:1727-1743.

Mayland, H.F. 1986. Factors affecting yield and nutritional quality of crested wheatgrass. p. 215-266. In K.L. Johnson (ed.). Crested wheatgrass and its values, problems, and myths. Utah State Univ. Logan.

Mayland, H.F., and K.H. Asay. 1989. Genetic Variability of $\mathrm{Mg}$, $\mathrm{Ca}$, and $\mathrm{K}$ in crested wheatgrass. J. Range Manage. 42:109-113.

Mayland, R.F., and D.L. Grunes. 1979. Soil-climate-plant relationships in the etiology of grass tetany p. 123-175. In V.V. Rendig and D.L. Grunes (ed.). Grass tetany. ASA Spec. Publ. 35. ASA, CSSA, and SSSA, Madison, WI.

National Academy of Sciences/National Research Council. 1976. Nutrient Requirements of Beef Cattle. 5th ed. NAS-NRC Publ. 4. National Academy of Science, Washington, DC.

Nguyen, H.T., and D.A. Sleper. 1981. Genetic variability of mineral element concentrations in Festuca arundinacea Schreb. Theor. Appl. Genet. 59:57-63.

Reid, R.L., and L.F. James. 1985. Forage-animal disorders. p. 430 444. In M.E. Heath et al. (ed.) Forages. 4th ed. Iowa State Univ. Press, Ames.

Sleper, D.A. 1979., Plant breeding, selection, and species in relation to grass tetany. p. 63-77. In V.V. Rendig and D.L. Grunes (ed.) Grass tetany. ASA Spec. Publ. 35. ASA, CSSA, and SSSA, Madison, WI.

Sleper, D.A., G.B. Garner, C.J. Nelson, and J.L. Sebaugh. 1980. Mineral concentration of tall fescue genotypes grown under controlled conditions. Agron. J. 72:720-722.

Steele, R.G.D., and James H. Torrie. 1960. Principles and procedures of statistics. McGraw-Hill Book Co., Inc., New York.

Vogel, K.P., P.E. Reece, and J.F.S. Lamb. 1984. Evaluation of crested wheatgrass introductions for forage yield and quality. Nebraska Agric. Exp. Stn. Res. Bull. 304.

Working Party on Nutrient Requirements of Ruminants. 1980. The nutrient requirements of ruminant livestock. Commonwealth Agric. Bureaux on behalf of the Agric. Res. Counc. Farnham Royal, England. 